\title{
Autosomal dominant retinitis pigmentosa (ADRP): a rhodopsin mutation in a Scottish family
}

\author{
C Bell, C A Converse, M F Collins, L Esakowitz, K F Kelly, N E Haites
}

The term retinitis pigmentosa describes a range of hereditary degenerative disorders of the retina, which are both clinically and genetically heterogeneous. Autosomal dominant retinitis pigmentosa (ADRP) accounts for $22 \%$ of the retinitis pigmentosa population. ${ }^{1}$ Linkage of an ADRP locus to the marker D3S47 on the long arm of chromosome 3 (3q) has been established. ${ }^{2}$ Rhodopsin, the major integral membrane protein of the rod outer cells and also located on $3 \mathrm{q},{ }^{3}$ was an obvious candidate gene. An intensive search for muta- tions in the rhodopsin gene of RP patients has shown several different mutations. ${ }^{4-6}$

We searched for mutations in the rhodopsin gene of a Scottish family defined as having the diffuse type ${ }^{7}$ of ADRP (referred to as ADRP3 in reference 8 and $T$ family in reference 9 ). Using direct sequencing, affected members of the family were shown to be heterozygous for the point mutation (TAC to TGC) in codon 178 of the rhodopsin gene (fig 1). This mutation, previously described, ${ }^{56}$ results in the substitution of a tyrosine residue by a cysteine
Medical Genetics, Department of Molecular and Cell Biology, University Medical School, Foresterhill,

Aberdeen AB9 2ZD.

C Bell

K F Kelly

N E Haites

Department of

Pharmaceutical

Sciences, University of Strathclyde, Glasgow G1 1XW.

C A Converse

M F Collins

Eye Clinic, Royal

Alexandra Hospital,

Paisley.

L Esakowitz

Correspondence to Dr Haites.

Received 17 January 1992.

Revised version accepted 5 March 1992.
A

B

Figure 1 Nucleotide sequence encompassing the base substitution at codon 178 (TAC-TGC) in exon 3 of the rhodopsin gene. The affected subject $(A)$ is heterozygous for the mutation and the unaffected (B) has the normal sequence. The amino acids coded by this sequence are denoted alongside the sequence.

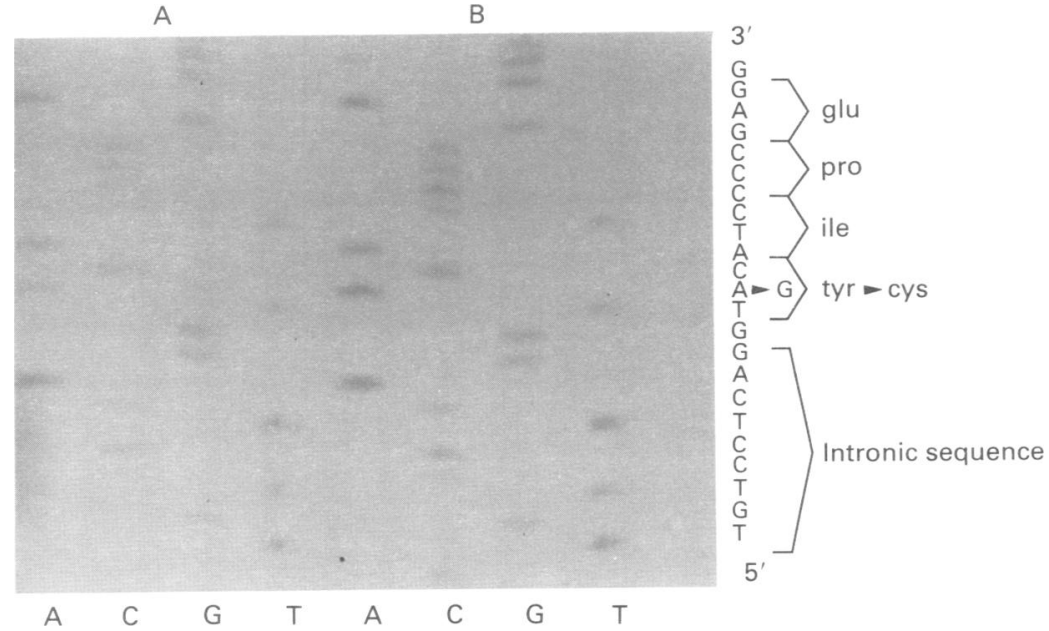

Figure 2 Alignment of the gel, showing RsaI digested exon 3 PCR products, with the pedigree. Tracks are numbered 1 to 19 as shown and correspond with the above numbered subjects in the pedigree. Unaffected subjects have fragments of 166, 105, and $76 \mathrm{bp}$ and affected subjects, heterozygous for the mutation, have a fragment of $271 \mathrm{bp}$ in addition to these. Lane 20 is size standard $k b$ ladder. 
residue in the first codon of exon 3. The mutation also destroys an $R s a I$ site and thus RP patients may be screened quickly for the presence of the mutation by simple restriction analysis. The segregation of the mutation with the disease in this family is shown in fig 2 .

Codon 178 occurs in an intradiscal loop of rhodopsin which is implicated in determining normal rhodopsin tertiary structure. ${ }^{10}$ It is likely that a mutation alters this structure, which in turn causes changes related to the pathogenesis of the disease.

The family also shows significantly decreased levels of certain polyunsaturated acids in the plasma of affected subjects compared to unaffected relatives. ${ }^{9}$ It is possible that a gene involved in the synthesis or transport of these fatty acids is linked to the rhodopsin gene.

Although the exact mechanism is unknown, knowledge of the actual mutation presents an opportunity for accurate counselling of affected persons.

We would like to thank The Wellcome Trust, the National Retinitis Pigmentosa Foundation, and the George Gund Foundation for their support in funding this research and also the
Medical Illustration department at Aberdeen University for their help with the graphics.

1 Bundey S, Crews SJ. A study of retinitis pigmentosa in the city of Birmingham. II. Clinical and genetic heterogeneity. 7 Med Genet 1984;21:421-8.

2 McWilliam P, Farrar GJ, Kenna P, et al. Autosomal dominant retinitis pigmentosa (ADRP): localisation of an ADRP gene to the long arm of chromosome 3. Genomics 1989;5:619-22.

3 Sparkes RS, Mohandas T, Newman SL, et al. Assignment of the rhodopsin gene to human chromosome 3. Invest Ophthalmol Vis Sci 1986;27:1170-2.

4 Dryja TP, McGee TL, Reichel E, et al. A point mutation of the rhodopsin gene in one form of retinitis pigmentosa. Nature 1990;343:364-6.

5 Sung CH, Davenport CM, Hennessey JC, et al. Rhodopsin mutations in autosomal dominant retinitis pigmentosa. Proc Natl Acad Sci USA 1991;88:6481-5.

6 Farrar GJ, Kenna P, Redmond R, et al. Autosomal dominant retinitis pigmentosa: a mutation in codon 178 of the ant retinitis pigmentosa: a mutation in codon 178 of the rhodopsin gene in

7 Lyness AL, Ernst W, Quinlan MP, et al. A clinical, psychophysical, and electroretinographic survey of patients with autosomal dominant retinitis pigmentosa. $\mathrm{Br} \mathcal{f}$ Ophthalmol 1985;69:326-39.

8 Lester DH, Inglehearn CF, Bashir R, et al. Linkage to D3S47 (C17) in one large autosomal dominant retinitis pigmentosa family and exclusion in another: confirmation of genetic heterogeneity. Am $\mathcal{F}$ Hum Genet 1990;47:53641 .

9 Converse CA, McColl AJ, McLachlan T, et al. Synthesis of n-3 polyunsaturated fatty acids in retinitis pigmentosa. In: Anderson RE, Hollyfield JG, LaVail MM, eds, Retinal degenerations. Boca Raton, Florida: CRC Press, 1991:143-50.

10 Doi T, Molday RS, Khorana HG. Role of the intradíscal domain in rhodopsin assembly and function. Proc Nat Acad Sci USA 1990;87:4991-5. 